THE JOURNAL OF INFECTIOUS DISEASES - VOL. 158, NO. 4 - OCTOBER 1988

(C) 1988 by The University of Chicago. All rights reserved. $0022-1899 / 88 / 5804-0003 \$ 01.00$

\title{
Fibronectin, Fibrinogen, and Laminin Act as Mediators of Adherence of Clinical Staphylococcal Isolates to Foreign Material
}

\author{
Mathias Herrmann, Pierre E. Vaudaux, Didier Pittet, \\ Raymond Auckenthaler, P. Daniel Lew, \\ Françoise Schumacher-Perdreau, Georg Peters, \\ and Francis $\mathbf{A}$. Waldvogel
}

\author{
From the Infectious Diseases Division, University Hospital, \\ Geneva, Switzerland; and the University of Cologne, \\ Cologne, Federal Republic of Germany
}

\begin{abstract}
Bacterial adherence to polymer surfaces is a required early step in intravenous (iv) device infection. We collected eight strains of Staphylococcus aureus and 19 of coagulase-negative staphylococci from patients with proven iv device bacteremia and studied the role of plasma or connective-tissue proteins in promoting bacterial adherence to polymethylmethacrylate (PMMA) coverslips. Although only a negligible percentage of organisms adhered to albumin-coated PMMA, surface-bound fibronectin significantly promoted adherence of all isolates. Fibrinogen markedly promoted adherence of all $S$. aureus strains but of only four coagulase-negative strains. Thus, coagulase-negative staphylococci revealed a marked heterogeneity in adherence to fibrinogen-coated surfaces, a result suggesting the existence of heretofore unknown receptors for fibrinogen. Laminin promoted adherence of staphylococci to a much lower extent. Although strain specific, adherence of clinical staphylococcal isolates to foreign surfaces is significantly increased by fibronectin, fibrinogen, and laminin, an observation suggesting the possible contribution of these proteins to the pathogenesis of iv device infection.
\end{abstract}

Adherence of microorganisms to specific substrates is presently considered to be a crucial step in the initiation of infections [1]. Many investigators have searched for such ligands in staphylococcal prosthesis infection. There is increasing evidence that similar specific interactions might also play a role in the pathogenesis of foreign-body infections.

After contact with blood, a polymer surface (such as a cannula inserted iv) is almost immediately coated with a protein layer at the blood-polymer interface [2-4]. Bacterial adherence to the protein-coated surface is a prerequisite for initiating iv device infection. Fibrinogen and fibronectin are proteins known to bind and to aggregate staphylococci $[5,6]$. More recently, laminin, a large glycoprotein mainly found

Received for publication 2 December 1987 and in revised form 7 April 1988.

This paper was presented in part at the 27th Interscience Conference on Antimicrobial Agents and Chemotherapy (abstract 503), held on 4-7 October 1987, in New York, New York.

This work was supported by grant 3.829-0.87 from the Swiss National Research Foundation.

We thank Elzbieta Huggler for technical assistance, Dr. Ingeborg Filthuth and Chantal Genier for isolation and characterization of the bacterial isolates, and Paule Schilling-Doriot for manuscript preparation.

Please address requests for reprints to Dr. Mathias Herrmann, Infectious Diseases Division, Department of Medicine, University Hospital, CH-1211 Geneva 4, Switzerland. in basal membranes and to a slight extent in plasma, has also been described as possessing staphylococcalbinding properties [7]. Several studies have investigated staphylococcal adherence [8-11] to polymer surfaces. In particular, studies performed on explanted foreign bodies $[12,13]$ and on in vitro models $[14,15]$ strongly suggested that adherence of selected staphylococcal strains was promoted by fibronectin. The relative role of these various plasma proteins in promoting adherence of clinically relevant strains has not yet, however, been studied in detail. In this paper we analyzed adherence of bacteremic strains of Staphylococcus aureus and coagulase-negative staphylococci to polymer surfaces and, in particular, the influence of surface-bound fibronectin, fibrinogen, and laminin.

\section{Materials and Methods}

Chemicals and materials. PBS solutions containing $1 \mathrm{mM} \mathrm{Ca} \mathrm{Ca}^{++}$and $0.5 \mathrm{mM} \mathrm{Mg}^{++}$were purchased from GIBCO (Paisley, Scotland); $\left[{ }^{3} \mathrm{H}\right]$ thymidine was purchased from Amersham (Buckinghamshire, England).

Fibronectin was purified as previously described [13]. Fibrinogen (provided by Dr. Haeberli, University Hospital, Bern, Switzerland) was further purified from trace amounts of fibronectin by affinity 
chromatography on gelatin-Sepharose 4B [13], and the final protein concentration was determined by the Bio-Rad ${ }^{\circledR}$ protein assay (Bio-Rad Laboratories, Glattbrugg, Switzerland). Laminin was purchased from Bioreba-Diagnostica (Basel, Switzerland). Examination of the different proteins by using $7 \%$ SDSPAGE under reducing conditions [16] revealed the expected bands; no significant contaminants were seen. All protein solutions were dispensed into aliquots and stored at $-70 \mathrm{C}$. Coverslips $(1 \times 1 \mathrm{~cm})$ made of polymethylmethacrylate (PMMA) were cleaned with $100 \%$ ethanol and sterilized by heating at $49 \mathrm{C}$ for $30 \mathrm{~min}$.

Staphylococcal isolates. We investigated 62 strains of staphylococci that, according to the clinical data obtained, were subdivided into three different groups. These strains were isolated from patients at the University Hospital of Geneva (Geneva), from patients at the University Hospital of Cologne (Cologne, FRG), and from healthy volunteers. Two additional clinical strains were provided by Dr. G. Christensen (University of Tennessee, Memphis).

The three groups were defined as follows. Group 1 included strains isolated from iv device infection. Twenty-seven isolates were obtained from 27 patients with proven septicemia associated with an iv device. This classification was based on the following criteria: (I) two or more positive cultures of blood yielding the same organism; (2) fever $>38 \mathrm{C}$ that was frequently associated with chills and sometimes associated with hemodynamic alterations (tachycardia, hypotension, low central-venous pressure); (3) leukocytosis $\left(>10000 / \mathrm{mm}^{3}\right)$; (4) positive culture of the catheter tip yielding the same organism and antibiogram as found in the cultures of blood (available in 24 of 27 cases); and (5) presence of an iv device, inserted before the onset of infection, in a patient showing clinical signs of acute inflammation and who improved after removal of the device and initiation of antibiotic therapy. The clinical data were evaluated twice and independently by two investigators (M. H. and D. P.).

Group 2 included strains from patients with septicemia. Nineteen isolates were obtained from $18 \mathrm{pa}-$ tients who met the aforementioned criteria, except the septicemia was not associated with an iv device infection.

Group 3 included strains from controls. Sixteen isolates were derived from the skin of healthy volunteers.

All isolates were identified as staphylococci in the
Table 1. Number of isolates and identification of investigated staphylococcal strains.

\begin{tabular}{|c|c|c|c|c|}
\hline \multirow[b]{3}{*}{ Strain } & \multicolumn{4}{|c|}{ No. of strains } \\
\hline & \multirow[b]{2}{*}{ Total } & \multicolumn{2}{|c|}{ Associated with } & \multirow[b]{2}{*}{ Contro } \\
\hline & & $\begin{array}{c}\text { Iv } \\
\text { devices }\end{array}$ & Septicemia & \\
\hline S. aureus & 24 & 8 & 14 & 2 \\
\hline \multicolumn{5}{|l|}{ Coagulase-negative } \\
\hline staphylococci & 38 & 19 & 5 & 4 \\
\hline \multicolumn{5}{|l|}{ Staphylococcus } \\
\hline epidermidis & 22 & 14 & 3 & 5 \\
\hline \multicolumn{5}{|l|}{ Staphylococcus } \\
\hline haemolyticus & 5 & 3 & & 2 \\
\hline \multicolumn{5}{|l|}{ Staphylococcus } \\
\hline hyicus & 1 & 1 & & \\
\hline $\begin{array}{l}\text { Staphylococcus } \\
\text { xylosus }\end{array}$ & 1 & & & 1 \\
\hline \multicolumn{5}{|l|}{ Staphylococcus } \\
\hline warneri & 4 & & 1 & 3 \\
\hline \multicolumn{5}{|l|}{ Staphylococcus } \\
\hline simulans & 1 & & & 1 \\
\hline Staphylococcus spp.* & 4 & 1 & 1 & 2 \\
\hline
\end{tabular}

* These strains could not be identified.

diagnostic microbiology laboratories of the University Hospital of Geneva and the University Hospital of Cologne. Species identification was performed according to the procedure described by Kloos and Schleifer [17]. The results of bacterial and clinical determinations are shown in table 1.

Slime production was assessed qualitatively by using the tube method and quantitatively by adherence of organisms to tissue culture plates and by spectrophotometric determination, as previously described by Christensen et al. [18, 19]. All strains were kept on Mueller-Hinton agar plates at $4 \mathrm{C}$.

Preparation of bacteria for adherence experiments. Each clinical or laboratory isolate of a fresh overnight culture was grown and radiolabeled with $\left[{ }^{3} \mathrm{H}\right]$ thymidine, as previously described [15], in Mueller-Hinton broth for $3 \mathrm{~h}$ at $37 \mathrm{C}$ (final concentration, $2 \times 10^{7}-2 \times 10^{8} \mathrm{cfu}$ ). After the labeling period and rinsing procedures [15], in most experiments the strains were sonicated to remove possible bacterial exopolymers [20] by using a B-12 sonifier (Branson, Danbury, Conn) for $10 \mathrm{~s}$ (with 50 watts) and were centrifuged. The strains were finally suspended in saline and standardized for $\mathrm{cfu}$ and $\mathrm{cpm}$ [15].

Attachment of strains to protein-coated coverslips. Adherence conditions were found to be op- 
timal $\left(0.5 \mu \mathrm{g}\right.$ of fibronectin $\left./ \mathrm{cm}^{2}\right)$ after coating PMMA coverslips with $25 \mu \mathrm{g}$ of fibronectin $/ \mathrm{mL}$ of buffer solution [15]. Others have shown that fibrinogen binds at a concentration of $35 \mu \mathrm{g} / \mathrm{mL}$ to a nearly saturated extent to polymethacrylate $(0.25 \mu \mathrm{g}$ of fibrinogen $/ \mathrm{cm}^{2}$ ) [21] and that optimal concentrations of laminin for adherence of $S$. aureus to surfaces were found to be $25 \mu \mathrm{g} / \mathrm{mL}$ [22]. To assess the amount of deposited laminin, we immersed multiple coverslips in a solution containing $25 \mu \mathrm{g}$ of laminin $/ \mathrm{mL}$ and measured the protein concentration in the solution before and after immersion. The average deposit was found to be $0.3 \mu \mathrm{g}$ of laminin $/ \mathrm{cm}^{2}$. With indirect immunofluorescence, we could demonstrate that laminin was homogeneously deposited on PMMA coverslips.

Each coverslip was immersed in a $1-\mathrm{mL}$ solution of PBS containing either fibronectin $(25 \mu \mathrm{g} / \mathrm{mL})$, fibrinogen $(35 \mu \mathrm{g} / \mathrm{mL})$, or laminin $(25 \mu \mathrm{g} / \mathrm{mL})$ for $1 \mathrm{~h}$ at $37 \mathrm{C}$. After being rinsed as previously described [15], protein-coated coverslips were incubated with $10^{6}-10^{7}$ radiolabeled bacteria (as determined by cfu counts) for $60 \mathrm{~min}$ at $37 \mathrm{C}$. The adherence medium was PBS containing divalent cations with or without $0.5 \%$ human serum albumin (as indicated in the text). At the end of the attachment period, the fluids containing unbound bacteria were removed, and the coverslips were rinsed and counted for radioactivity. Background radioactivity was subtracted, and adherence was expressed as the percentage of radioactivity remaining on the coverslips divided by the amount of radioactivity used to label the coverslips. All experiments were performed in triplicate and were repeated on at least two different days.

Validation of the adherence assay. To minimize bacterial aggregation and to remove residual fragments of exopolymeric substances or slime $[18,20]$, we sonicated organisms, because adherence experiments with sonicated and nonsonicated organisms yielded no significant differences (median, $2.3 \%$ and $2.4 \%$, respectively; $n=23$ ). To rule out possible dayto-day variations in the number of inoculated bacteria, we tested four staphylococcal strains, each with 20-fold different concentrations of inoculated organisms (table 2). The number of bacteria bound to PMMA was proportional to the number of bacteria inoculated; thus no significant difference in the percentage of bound bacteria (depending on the inoculum size) could be found in our assay. Time courses revealed that optimal adherence conditions were observed after incubation for $60 \mathrm{~min}$ (results not
Table 2. Adherence of different numbers of inoculated organisms to polymethylmethacrylate.

\begin{tabular}{ll}
\hline $\begin{array}{l}\text { Strain, no. of } \\
\text { inoculated } \\
\text { organmisms }\end{array}$ & Percent adherence \\
\hline S. aureus Cowan 1 & \\
$2 \times 10^{8}$ & 0.63 \\
$6 \times 10^{6}$ & 0.4 \\
S. aureus BB & \\
$3 \times 10^{8}$ & 4.1 \\
$7 \times 10^{6}$ & 4.4 \\
S. epidermidis Sp2 & \\
$5 \times 10^{7}$ & 0.02 \\
$2 \times 10^{6}$ & 0.02 \\
S. epidermidis Rp12 & \\
$3 \times 10^{8}$ & 0.6 \\
$6 \times 10^{6}$ & 0.4 \\
\hline
\end{tabular}

NOTE. Staphylococcal organisms at the indicated concentrations (20-fold differences) were incubated with coverslips precoated with fibronectin $(25 \mu \mathrm{g} / \mathrm{mL})$ in the presence of $0.5 \%$ albumin; adherence was assessed as described in Materials and Methods. The results are averages of triplicate experiments.

shown). Variations in the quantity of proteins adsorbed on PMMA did not affect adherence, because staphylococci adhered to almost the same extent to surfaces coated with a fivefold lower concentration of proteins (results not shown).

Statistical analysis. The Mann-Whitney test for unrelated scores, the Wilcoxon test for related rankable scores, and the Fisher's exact test were performed by using specific programs adapted to a computer (model HP-41C; Hewlett-Packard, Geneva; or MacIntosh; Apple, Cubertino, Calif).

\section{Results}

Adherence to uncoated coverslips and influence of albumin on adherence. In vitro assays, testing characteristics of bacterial adherence to artificial surfaces in the absence of blood proteins, have shown that there is adherence due to electrical charge and to other physicochemical binding forces [11]. To evaluate staphylococcal adherence to uncoated PMMA coverslips, in the absence of serum proteins, we incubated 23 clinical isolates obtained from septicemic patients with iv device infection (seven isolates of S. aureus and 16 of coagulase-negative strains) with uncoated coverslips in PBS without albumin. Adherence is shown in figure 1A. $S$. aureus strains adhered more homogeneously and more strongly to PMMA (median, 2.1\%; range, 1.3\%-2.3\%) than did 


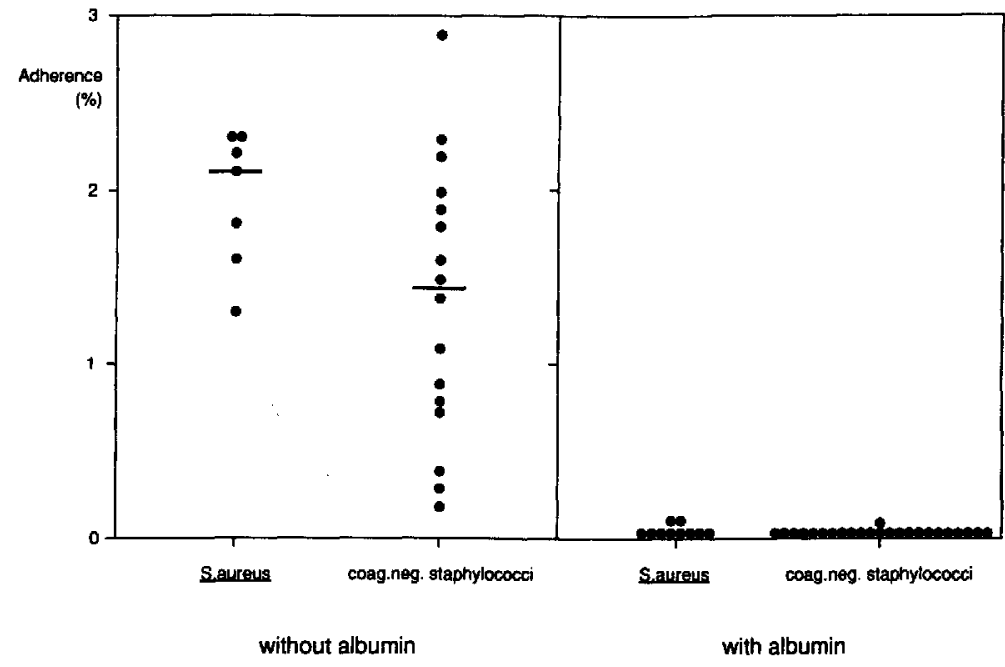

Figure 1. Staphylococcal adherence to uncoated polymethylmethacrylate (PMMA). Sterile PMMA coverslips were incubated for $60 \mathrm{~min}$ at $37 \mathrm{C}$ in PBS in the absence (left) or presence (right) of $0.5 \%$ albumin with $5 \times 10^{6}$ $\mathrm{cfu}$ of radiolabeled strains obtained from patients with iv device infections ( $S$. aureus, seven isolates; coagulasenegative staphylococci, 16 isolates). Each dot indicates the average of adherent radioactivity of triplicate determinations performed twice. The bars indicate the median of the plotted values. the coagulase-negative staphylococci (median, $1.25 \%$; range, $0.2 \%-2.9 \%$ ), but this difference was not significant.

Implanted or inserted foreign bodies, such as iv catheters, are rapidly covered to a variable degree with serum proteins and blood cell deposits [23, 24]. Thus, $0.5 \%$ human serum albumin was added to the medium (figure 1B). We found a striking reduction of adherence: $S$. aureus strains had $0.009 \%$ (median) adherence to PMMA and the coagulase-negative strains, $0.003 \%$ adherence. Therefore, albumin inhibited nonspecific adherence to $>99 \%$. We considered these observations to be maximum inhibition of nonspecific bacterial adherence and performed all further experiments in the presence of $0.5 \%$ human serum albumin in the incubation assay.

Adherence of $S$. aureus and coagulase-negative staphylococci to surface-bound proteins. S. aureus and coagulase-negative strains that had been ob- tained from cultures of blood from patients with iv device infection were tested for adherence to proteincoated PMMA substrates (table 3). S. aureus adhered significantly more than did coagulase-negative staphylococci to fibronectin-coated $(P<.02)$ and fibrinogen-coated $(P<.002)$ PMMA. In comparison, adherence to surface-bound laminin did not differ as much; however, the $S$. aureus strains also adhered more to laminin than did the coagulase-negative strains $(P<.02)$.

Promotion of adherence by surface-bound proteins. Adherence of the eight strains of $S$. aureus from iv device infections was strongly promoted by surface-bound fibronectin (median increase, 307fold; range, 177-425-fold) and surface-bound fibrinogen (median, 335-fold; range, 289-525-fold; figure 2, left) when compared with albumin-coated PMMA. In contrast, promotion of adherence by surface-bound laminin was significantly $(P<.02)$

Table 3. Adherence of strains from iv devices to protein-coated polymethylmethacrylate (PMMA).

\begin{tabular}{lccc}
\hline $\begin{array}{l}\text { Strain (no. } \\
\text { of isolates) }\end{array}$ & Fibronectin & \multicolumn{2}{c}{ Percent adherence to PMMA coated with } \\
\hline $\begin{array}{l}S . \text { aureus (8) } \\
\begin{array}{l}\text { Coagulase-negative } \\
\text { staphylococci (19) }\end{array}\end{array}$ & $2.6(1.5-3.6)^{*}$ & $2.85(2.25-4.45)^{\dagger}$ & Laminin \\
\hline
\end{tabular}

NOTE: Data are the medians (ranges) of triplicate experiments. $S$. aureus and coagulase-negative isolates were incubated with coverslips precoated with either fibronectin $(25 \mu \mathrm{g} / \mathrm{mL})$, fibrinogen $(35 \mu \mathrm{g} / \mathrm{mL})$, or laminin $(25 \mu \mathrm{g} / \mathrm{mL})$ in the presence of $0.5 \%$ human serum albumin and were assessed for adherence, as described in Materials and Methods.

* $\boldsymbol{P}<.02$, compared with coagulase-negative staphylococci, by using the two-tailed Mann-Whitney test.

$\dagger P<.002$, compared with coagulase-negative staphylococci, by using the two-tailed Mann-Whitney test. 
Figure 2. Promotion of adherence to polymethylmethacrylate (PMMA) of iv device-associated staphylococci by surface-bound proteins. Radiolabeled organisms $\left(5 \times 10^{6} \mathrm{cfu}\right)$ were incubated with PMMA coverslips precoated with the indicated proteins in the presence of $0.5 \%$ albumin. Results are expressed as fold increase of adherence compared with incubation with albumin-coated coverslips, as described in Materials and Methods. The dots indicate the average results of triplicate determinations. The bars indicate the median of the plotted values.

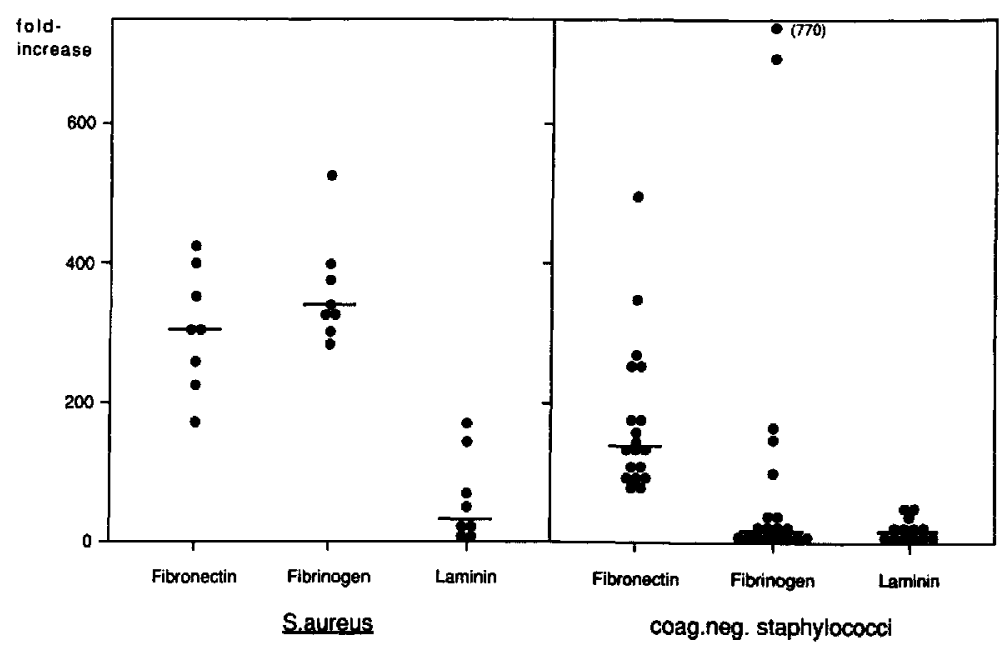

lower (median, 37-fold; range, 4-163-fold). Furthermore, laminin-promoted adherence showed greater strain variability, with half of the strains being poorly promoted $(<20$-fold) and the other half being more strongly promoted ( $>50$-fold).

Adherence of the 19 coagulase-negative strains from iv device infection was more strongly promoted by surface-bound fibronectin (median increase, 140fold; range, 80-495-fold) than by surface-bound fibrinogen (median, 16-fold; range, 3-722-fold; figure 2, right). Closer analysis of these data revealed a heterogeneous response of coagulase-negative staphylococci to surface-bound fibrinogen. Adherence of 15 coagulase-negative strains (10 of S. epidermidis, 3 of $S$. haemolyticus, and 2 Staphylococcus spp.) was slightly (median, 13-fold) promoted. In contrast, adherence of four coagulase-negative strains (three of $S$. epidermidis and one of S. hyicus) was promoted to a larger extent by fibrinogen (median, 430-fold), and the two most-adherent strains were agglutinated by purified fibrinogen. Adherence of the coagulase-negative staphylococci to laminin-coated PMMA was only slightly promoted (median, 11-fold; range, 1-50-fold).

Adherence of iv device-associated, septicemic, and control isolates. Adherence of strains that had been obtained from cultures of blood from patients with iv device infection did not differ significantly from adherence of strains obtained from patients with septicemia of other origin (figure 3 ).

In contrast, we found adherence of coagulasenegative, clinical isolates versus control isolates to fibrinogen to be significantly different (figure 3 , bottom right). Defining an arbitrary breakpoint, we found that adherence of only 3 of 14 control strains was $>10$-fold promoted, whereas adherence of 12 of 19 iv device-associated $(P<.05)$ and 4 of 5 sepsisassociated $(P<.05)$ strains was $>10$-fold promoted.

Slime production and promotion of adherence of coagulase-negative staphylococci. Slime production was first quantitatively examined with the spec-

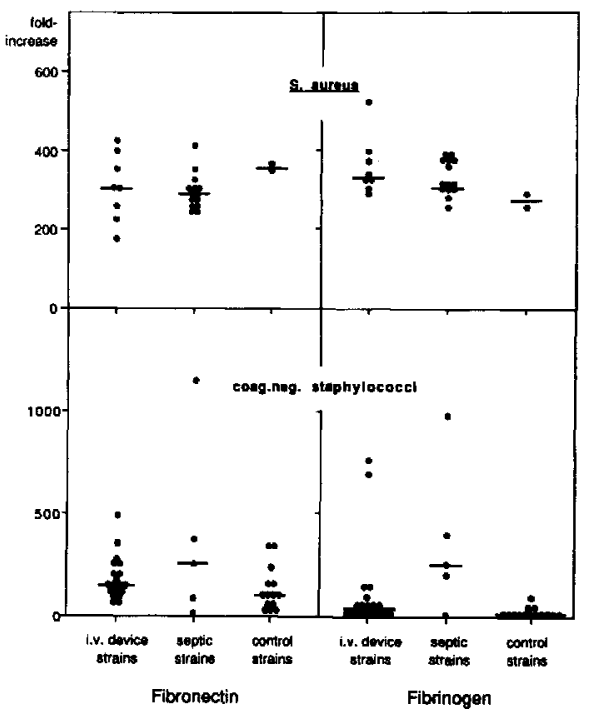

Figure 3. Promotion of adherence of staphylococci from various sources by surface-bound proteins. $S$. aureus and coagulase-negative strains obtained from the blood of patients with an iv device infection or with sepsis of another origin, as well as strains obtained from controls, were assessed for adherence to polymethylmethacrylate coverslips precoated with the indicated proteins, as described in Materials and Methods. 
trophotometric method [19]. Four of 35 coagulasenegative clinical and control isolates were found to be negative for slime production (OD, at $A_{570},<0.24$ ), whereas 31 of 35 isolates were positive (OD, at $A_{570}$, $>0.24)$ when tested on tissue culture dishes. Both positive and negative strains adhered, however, to a similar extent to surface-bound fibronectin (median of promotion, 115- and 301-fold, respectively) or fibrinogen (median, 10- and 82-fold, respectively); no significant differences between the groups were found. Furthermore, no quantitative correlation could be found when values of slime production assessed by OD were compared with adherence to fibronectin-coated PMMA $(r=.1)$ or to fibrinogencoated PMMA $(r=.1)$. In addition, we assessed slime production with a more qualitative test (tube test [18]) and found that nine of 35 coagulasenegative strains were negative for slime production. Organisms positive for slime production adhered to fibronectin-coated PMMA to the same extent as did organisms negative for slime production (median promotion, 115- and 156-fold, respectively); the same was true for adherence to fibrinogen-coated PMMA (median, 263- and 137-fold, respectively). The differences were not significant.

\section{Discussion}

The present study focused on the early events of adherence of bacteremic staphylococcal isolates to artificial surfaces. For this purpose we used a previously described [15] in vitro assay established for S. aureus strain Wood 46. Because many materials are used for bioprosthesis and iv devices, we used PMMA, a polymer widely used in orthopedic surgery and proven to adsorb proteins to a similar extent when compared with other polymers used in iv catheters [25].

Bacteria adhere to uncoated polymer surfaces to a different extent depending on the surface charge and hydrophobicity of the material [10] and the organisms [26]. We found no significant difference in adherence to uncoated PMMA when comparing $S$. aureus with coagulase-negative staphylococci; the differences in adherence between the strains might be due to surface properties of the microorganisms influencing charge or hydrophobicity. Furthermore, we confirmed previously published results $[15,27$, 28] showing a striking inhibition of adherence of all our isolates to polymers by either human serum or albumin, probably due to a decreased hydrophobicity of the interacting surfaces.
Staphylococcal adherence was studied primarily on surfaces coated by a variety of host proteins presumed to be deposited on foreign surfaces and to react with staphylococcal surface receptors. Binding of staphylococci to fibronectin has been described as a specific, receptor-mediated process. Fibronectin-binding molecules of different molecular weight have been described [29-31], and recently a fibronectin-binding protein from $S$. aureus has been cloned and expressed [32]. Our findings demonstrated that adherence of all coagulase-positive and -negative clinical staphylococcal strains was significantly promoted by fibronectin. These results are consistent with previous studies investigating selected laboratory strains and showing staphylococcal binding to specific binding sites on soluble $[6,33-35]$ and surface-bound fibronectin $[14,15,28]$.

Fibrinogen is deposited, perhaps preferentially, on surfaces of iv devices, as demonstrated with ${ }^{125}$ Ilabeled fibrinogen in human [36] and animal [37] in vivo studies. Development of fibrinogen-associated thrombosis is a frequent complication of iv devices [38-40] and catheter infection [41, 42]. Adherence of all of the $S$. aureus isolates tested was highly promoted by surface-bound fibrinogen, and no significant differences were observed between the iv device-associated, septicemic, or control strains. $S$. aureus binds specifically to soluble fibrinogen in a reaction described as staphylococcal clumping reaction [43, 44] and to surface-bound fibrinogen [35], possibly via a recently described receptor protein [45]. Our observation of the extent of increased adherence of $S$. aureus to foreign surfaces because of fibrinogen therefore suggests a contribution of this protein to colonization and infection of catheters with $S$. aureus. In contrast, $S$. epidermidis is generally considered to be nonadherent to fibrinogen [46], a belief suggesting less importance of this protein in the initiation of foreign-body infection. So far, adherence has only been described for some coagulase-negative strains, such as $S$. hyicus and Staphylococcus intermedius [47].

We found adherence of coagulase-negative staphylococci to fibrinogen to be heterogeneous. Although the majority of strains was only slightly adherent to fibrinogen, some coagulase-negative staphylococci strains were highly adherent to fibrinogen-coated surfaces. Bacteremic strains adhered to fibrinogen to a higher extent than did control strains. No difference was found between iv device-associated and septicemic strains in the bacteremic group. The nature of this interaction remains to be explored, as 
does the question of whether coagulase-negative staphylococci strains that bind to fibrinogen are more virulent in an animal model. In summary, our experiments suggest the existence of heretofore unknown ligands for fibrinogen on some coagulase-negative staphylococci associated with iv device infection.

In comparison with fibronectin and fibrinogen, much less is known concerning the interaction of staphylococci with surface-bound laminin, a large glycoprotein that has a molecular mass of 900 kilodaltons and that is found mainly in basal membranes [48]. Laminin has been shown to promote cellular [49-51] and bacterial [22] attachment to solid surfaces. Furthermore, soluble laminin binds to $S$. aureus but not to $S$. epidermidis, and a tentative receptor of $S$. aureus for laminin has been described [7]. Laminin is present in the serum of healthy persons in a concentration of $\sim 0.2 \mu \mathrm{g} / \mathrm{mL}$, and the serum concentration of laminin is increased in the presence of liver diseases [52]. We found that adherence was promoted for four of eight $S$. aureus strains, whereas adherence of all the tested coagulase-negative strains was uniformly weak. This finding is not due to a significantly lower adsorption of laminin on PMMA, compared with fibronectin or fibrinogen. In addition, coating PMMA with a fivefold or lower concentration of laminin produced no significant difference in adherence of a moderately promoted $S$. aureus strain. Because staphylococci adhered to laminin-coated PMMA to a lower degree and because the concentration of laminin in serum is $>100$-fold lower than in our adherence assay, it might be suggested that laminin contributes to a minor extent to the colonization of catheter surfaces.

Certain S. aureus and coagulase-negative strains produce an extracellular fibrous matrix of either polysaccharides or glycoproteins; this matrix has been designated as extracellular slime [18, 53, 54], glycocalyx [55], or bacterial exopolymeric substances [56]. Several published studies investigating the correlation between clinical invasiveness of staphylococcal strains and adherence properties to artificial surfaces have focused on their slime production as a causative factor $[12,18,56-63]$. Bacterial production of exopolymers is, however, a time-dependent process [18]. In contrast, bacteria must, in order to initiate colonization, quite instantly and under slimenegative conditions bind to artificial surfaces like catheters. Our experiments yielded no significant correlation between slime production and adherence to fibronectin- or fibrinogen-coated surfaces. Therefore, the conceivably early organism-substrate inter- action might not be conditioned by the ability of the organism to produce slime. Thus, slime production may play a minor role during the initial steps of bacterial adherence leading to the permanent colonization of implants or inserted devices [20].

Recent evidence from our laboratory suggests that adherence of $S$. aureus and, to a lesser extent also, of coagulase-negative staphylococci to ex vivo catheter material is promoted by surface-adherent plasma proteins, probably due to a significant amount of deposited fibrinogen and/or fibronectin, as determined by a specific RIA (P. E. V., unpublished data). These data might indicate relevance of our findings in the in vivo situation.

In conclusion, our results imply an important role for two major plasma proteins, namely fibronectin and fibrinogen, and a minor role for laminin in staphylococcal adherence to polymer surfaces and thus in mediating the early steps of colonization of catheter surfaces. Further studies, however, are necessary to relate these results to the in vivo conditions of inserted iv devices.

\section{References}

1. Quie PG, Belani KK. Coagulase-negative staphylococcal adherence and persistence. J Infect Dis 1987;156:543-7

2. Baier RE. The organization of blood components near interfaces. Ann NY Acad Sci 1977;283:17-36

3. Cottonaro CN, Roohk HV, Shimizu G, Sperling DR. Quantitation and characterization of competitive protein binding to polymers. Transactions of the American Society for Artifical Internal Organs 1981;27:391-5

4. Kochwa S, Litwak RS, Rosenfield RE, Leonard EF. Blood elements at foreign surfaces: a biochemical approach to the study of the adsorption of plasma proteins. Ann NY Acad Sci 1977;283:37-49

5. Hawiger J, Hammond DK, Timmons S, Budzynski AZ. Interaction of human fibrinogen with staphylococci: presence of a binding region on normal and abnormal fibrinogen variants and fibrinogen derivatives. Blood 1978;51: 799-812

6. Kuusela P. Fibronectin binds to Staphylococcus aureus. Nature 1978;276:718-20

7. Lopes JD, dos Reis M, Brentani RR. Presence of laminin receptors in Staphylococcus aureus. Science 1985;229:275-7

8. Ashkenazi S, Mirelman D. Adherence of bacteria to pediatric intravenous catheters and needles and its relation to phlebitis in animals. Pediatr Res 1984;18:1361-6

9. Franson TR, Sheth NK, Rose HD, Sohnle PG. Quantitative adherence in vitro of coagulase-negative staphylococci to intravascular catheters: inhibition with D-mannosamine. J Infect Dis 1984;149:116

10. Hogt AH, Dankert J, Feijen J. Adhesion of coagulase-negative staphylococci to methacrylate polymers and copolymers. J Biomed Mater Res 1986;20:533-45

11. Dankert J, Hogt AH, Jeijen J. Biomedical polymers: bac- 
terial adhesion, colonization, and infection. CRC Critical Reviews of Biocompatibility 1986;2:219-301

12. Peters G, Locci R, Pulverer G. Adherence and growth of coagulase-negative staphylococci on surfaces of intravenous catheters. J Infect Dis 1982;146:479-82

13. Vaudaux P, Suzuki R, Waldvogel FA, Morgenthaler JJ, Nydegger UE. Foreign body infection: role of fibronectin as a ligand for the adherence of Staphylococcus aureus. J Infect Dis 1984;150:546-53

14. Maxe I, Rydén C, Wadström T, Rubin K. Specific attachment of Staphylococcus aureus adherence. Infect Immun 1986;54:695-704

15. Vaudaux PE, Waldvogel FA, Morgenthaler JJ, Nydegger UE. Adsorption of fibronectin onto polymethylmethacrylate and promotion of Staphylococcus aureus adherence. Infect Immun 1984;45:768-74

16. Laemmli UK. Cleavage of structural proteins during the assembly of the head of bacteriophage T4. Nature 1970; 227:680-5

17. Kloos WE, Schleifer KH. Genus IV. Staphylococcus. In: Sneath PHA, Mair NS, Sharpe ME, Holt JG, eds. Bergey's manual of systematic bacteriology. Vol. 2. Baltimore: William \& Wilkins, 1986:1013-35

18. Christensen GD, Simpson WA, Bisno AL, Beachey EH. Adherence of slime-producing strains of Staphylococcus epidermidis to smooth surfaces. Infect Immun 1982;37: 318-26

19. Christensen GD, Simpson WA, Younger JJ, Baddour LM, Barrett FF, Melton DM, Beachey EH. Adherence of coagulase-negative staphylococci to plastic tissue culture plates: a quantitative model for the adherence of staphylococci to medical devices. J Clin Microbiol 1985;22: 996-1006

20. Falcieri E, Vaudaux $P$, Huggler E, Lew D, Waldvogel F. Role of bacterial exopolymers and host factors on adherence and phagocytosis of Staphylococcus aureus in foreign body infection. J Infect Dis 1987;155:524-31

21. Lindon JN, McManama G, Kushner L, Merrill EW, Salzman EW. Does the conformation of adsorbed fibrinogen dictate platelet interactions with artificial surfaces? Blood 1986;68:355-62

22. Vercellotti GM, McCarthy JB, Lindholm P, Peterson PK, Jacob HS, Furcht LT. Extracellular matrix proteins (fibronectin, laminin, and type IV collagen) bind and aggregate bacteria. Am J Pathol 1985;120:13-21

23. Fuller RA, Rosen JJ. Materials for medicine. Sci Am 1986; 255:118-25

24. Murabayashi S, Nosé Y. Biocompatibility: bioengineering aspects. Artificial Organs 1986;10:114-21

25. Vaudaux $P$, Lerch $P$, Velazco MI, Nydegger UE, Waldvogel FA. Role of fibronectin in the susceptibility of biomaterial implants to bacterial infections. In: Christel P, Meunier A, Lee AJC, eds. Biological and biomedical performance of biomaterials. Amsterdam: Elsevier, 1986:355-60

26. Hogt AH, Dankert J, Feijen J. Adhesion of Staphylococcus epidermidis and Staphylococcus saprophyticus to a hydrophobic biomaterial. J Gen Microbiol 1985;131:2485-91

27. Fletcher $\mathrm{M}$, Marshall $\mathrm{KC}$. Bubble contact angle method for evaluating substratum interfacial characteristics and its relevance to bacterial attachment. Appl Environ Microbiol $1982 ; 44: 184-92$
28. Vaudaux PE, Lew D, Waldvogel FA. Host-dependent pathogenic factors in foreign body infection. A comparison between Staphylococcus epidermidis and $S$. aureus. In: Pulverer G, Quie PG, Peters G, eds. Pathogenicity and clinical significance of coagulase-negative staphylococci. Stuttgart, FRG: Gustav Fisher Verlag, 1987:183-93

29. Rydén C, Rubin K, Speziale P, Höök M, Lindberg M, Wadström T. Fibronectin receptors from Staphylococcus aureus. J Biol Chem 1983;258:3396-401

30. Espersen F, Clemmensen I. Isolation of a fibronectin-binding protein from Staphylococcus aureus. Infect Immun 1982; 37:526-31

31. Fröman G, Switalski LM, Speziale P, Höök M. Isolation and characterization of a fibronectin receptor from Staphylococcus aureus. J Biol Chem 1987;262:6564-71

32. Flock J-I, Fröman G, Jönsson K, Guss B, Signäs C, Nilsson B, Raucci G, Höök M, Wadström T, Lindberg M. Cloning and expression of the gene for a fibronectin-binding protein from Staphylococcus aureus. EMBO J 1987;6: 2351-7

33. Switalski LM, Rydén C, Rubin K, Ljungh $\AA$, Höök M, Wadström T. Binding of fibronectin to Staphylococcus strains. Infect Immun 1983;42:628-33

34. Proctor RA, Prendergast E, Mosher DF. Fibronectin mediates attachment of Staphylococcus aureus to human neutrophils. Blood 1982;59:681-7

35. Kuusela P, Vartio T, Vuento M, Myhre EB. Attachment of staphylococci and streptococci on fibronectin, fibronectin fragments, and fibrinogen bound to a solid phase. Infect Immun 1985;50:77-81

36. Lindblad B, Johansson A. ${ }^{125}$ I-Fibrinogen uptake on peripheral venous cannulas: a comparison between different cannula materials and coatings. J Biomed Mater Res 1987; 21:99-105

37. Horbett TA, Cheng CM, Ratner BD, Hoffman AS, Hanson SR. The kinetics of baboon fibrinogen adsorption to polymers: in vitro and in vivo studies. J Biomed Mater Res 1986;20:739-72

38. Peters WR, Bush WH Jr, McIntyre RD, Hill LD. The development of fibrin sheath on indwelling venous catheters. Surg Gynecol Obstet 1973;137:43-7

39. Welch GW, McKeel DW Jr, Silverstein P, Walker HL. The role of catheter composition in the development of thrombophlebitis. Surg Gynecol Obstr 1974;138:421-4

40. Brismar B, Hårdstedt C, Jacobson S. Diagnosis of thrombosis by catheter phlebography after prolonged central venous catheterization. Ann Surg 1981;194:779-83

41. Stillman RM, Soliman F, Garcia L, Sawyer PN. Etiology of catheter-associated sepsis. Correlation with thrombogenicity. Arch Surg 1977;112:1497-9

42. Ratcliffe FM. Suppurative thrombosis of the superior vena cava: a lethal complication of central venous catheters. Intensive Care Med 1985;11:265-6

43. Doolittle RF. Fibrinogen and fibrin. Annu Rev Biochem 1984;53:195-229

44. Allington MJ. Fibrinogen and fibrin degradation products and the clumping of staphylococci by serum. $\mathrm{Br} \mathrm{J}$ Haematol 1967;13:550-67

45. Usui Y. Biochemical properties of fibrinogen binding protein (clumping factor) of the staphylococcal cell surface. Zentralbl Bakteriol Mikrobiol Hyg [A] 1986;262:289-97 
46. Toy PTCY, Lai L-W, Drake TA, Sande MA. Effect of fibronectin on adherence of Staphylococcus aureus to fibrin thrombi in vitro. Infect Immun 1985;48:83-6

47. Leammler C, de Freitas JC, Chhatwal GS, Blobel H. Interactions of immunoglobulin $\mathrm{F}$, fibrinogen and fibronectin with Staphylococcus hyicus and Staphylococcus intermedius. Zentralbl Bakteriol Mikrobiol Hyg [A] 1985;260:232-7

48. Timpl R, Rohde H, Robey PG, Rennard SI, Foidart J-M, Martin GR. Laminin - a glycoprotein of basement membranes. J Biol Chem 1979;254:9933-7

49. Terranova VP, DiFlorio R, Hujanen ES, Lyall RM, Liotta LA, Thorgeirsson U, Siegal GP, Schiffmann E. Laminin promotes rabbit neutrophil motility and attachment. J Clin Invest 1986;77:1180-6

50. Nakatsuji N. Presumptive mesoderm cells from Xenopus laevis gastrulae attach to and migrate on substrata coated with fibronectin or laminin. J Cell Sci 1986;86:109-18

51. Perri RT, Vercellotti G, McCarthy J, Vessella RL, Furcht LT. Laminin selectively enhances monocyte-macrophage-mediated tumoricidal activity. J Lab Clin Med 1985;105:30-5

52. Gressner AM, Tittor W, Negwer A, Pick-Kober K-H. Serum concentrations of laminin and aminoterminal propeptide of type III procollagen in relation to the portal venous pressure of fibrotic liver diseases. Clin Chim Acta 1986;161: $249-58$

53. Peters G, Schumacher-Perdreau F, Jansen B, Bey M, Pulverer G. Biology of S. epidermidis extracellular slime. In: Pulverer G, Quie PG, Peters G, eds. Pathogenicity and clinical significance of coagulase-negative staphylococci. Stuttgart, FRG: Gustav Fischer Verlag, 1987:15-32

54. Ludwicka A, Uhlenbruck G, Peters G, Seng PN, Gray ED, Jeljaszewicz J, Pulverer G. Investigation on extracellular slime substance produced by staphylococcus epidermidis. Zentralbl Bakteriol Mikrobiol Hyg [A] 1984;258:256-67
55. Costerton JW, Irvin RT, Cheng K-J. The bacterial glycocalyx in nature and disease. Annu Rev Microbiol 1981;35: 299-324

56. Geesey GG. Microbial exopolymers: ecological and economic considerations. American Society for Microbiology Newsletter 1982;48:9-14

57. Peters G, Saborowski F, Locci R. Pulverer G. Investigations on staphylococcal infection of transvenous endocardial pacemaker electrodes. Am Heart J 1984;108:359-65

58. Kristinsson KG, Spencer RC, Brown CB. Clinical importance of production of slime by coagulase negative staphylococci in chronic ambulatory peritoneal dialysis. J Clin Pathol 1986;39:117 -8

59. Davenport DS, Massanari RM, Pfaller MA, Bale MJ, Streed SA, Hierholzer WJ Jr. Usefulness of a test for slime production as a marker for clinically significant infections with coagulase-negative staphylococci. J Infect Dis 1986;153: 332-9

60. Christensen GD, Simpson WA, Bisno AL, Beachey EH. Experimental foreign body infections in mice challenged with slime-producing Staphylococcus epidermidis. Infect Immun 1983;40:407-10

61. Ishak MA, Gröschel DHM, Mandell GL, Wenzel RP. Association of slime with pathogenicity of coagulase-negative staphylococci causing nosocomial septicemia. J Clin Microbiol 1985;22:1025-9

62. Diaz-Mitoma F, Harding GKM, Hoban DJ, Roberts RS, Low DE. Clinical significance of a test for slime production in ventriculoperitoneal shunt infections caused by coagulase-negative staphylococci. J Infect Dis 1987; 156:555-60

63. Younger JJ, Christensen GD, Bartley DL, Simmons JCH, Barrett FF. Coagulase-negative staphylococci isolated from cerebrospinal fluid shunts: importance of slime production, species identification, and shunt removal to clinical outcome. J Infect Dis 1987;156:548-54 